Board of Governors of the Federal Reserve System

International Finance Discussion Papers

Number 667

April 2000

\title{
EXCHANGE RATE DYNAMICS AND THE WELFARE EFFECTS OF MONETARY POLICY IN A TWO-COUNTRY MODEL WITH HOME-PRODUCT BIAS
}

Francis E. Warnock

NOTE: International Finance Discussion Papers are preliminary materials circulated to stimulate discussion and critical comment. References in publications to International Finance Discussion Papers (other than an acknowledgment that the writer has had access to unpublished material) should be cleared with the author or authors. Recent IFDPs are available on the Web at www.bog.frb.fed.us. 


\title{
EXCHANGE RATE DYNAMICS AND THE WELFARE EFFECTS OF MONETARY POLICY \\ IN A TWO-COUNTRY MODEL WITH HOME-PRODUCT BIAS
}

Francis E. Warnock ${ }^{*}$

\begin{abstract}
International spillovers and exchange rate dynamics are examined in a two-country dynamic optimizing model that allows for home-product bias in consumption patterns: at given relative prices the ratio of home goods consumed to foreign goods consumed is higher in the home country. The setup nests Obstfeld and Rogoff (1995), who assume identical tastes. With home bias, results are different in three ways. When preferences are biased, the wealth transfers associated with current account imbalances induce movements in the real exchange rate and produce large short-run and small long-run deviations from consumption-based purchasing power parity. With home bias, interest rates, both real and nominal, can differ across countries; relatedly, home bias is a necessary but not sufficient condition for Dornbusch (1976) type exchange rate overshooting. Finally, in this model the welfare effects of expansionary monetary policy depend not only on world demand but also on the expenditure-switching effect of an exchange rate depreciation; monetary policy is 'beggar-thy-neighbor' if individuals have strong preferences for domestic products, but can be 'beggar-thyself' if, instead, imported goods are preferred.
\end{abstract}

JEL Classification: F3, F4

Keywords: Home-product bias, welfare effects of monetary policy, beggar-thy-neighbor, purchasing power parity, dynamic optimizing model, exchange rate overshooting.

* This paper is based on chapter 2 of my dissertation at the University of North Carolina. I thank Stanley Black and Dale Henderson for guidance; Cedric Tille for helpful comments; and participants at the UNC Money/Macro Seminar, the 1997 Southeastern Economic Theory and International Economics Conference, and the workshop at the International Finance Division of the Board of Governors of the Federal Reserve System. Remaining errors are my own. The views in this paper are solely the responsibility of the author and should not be interpreted as reflecting the views of the Board of Governors of the Federal Reserve System or of any other person associated with the Federal Reserve System. E-mail: frank.warnock@frb.gov 
“The fact ... that purchasers in each country have a greater familiarity with ... their own country's products will cause purchasers ... to have some natural preference for the purchase of home products."

J.E. Meade (1951)

\section{Introduction}

International macroeconomic models have traditionally incorporated the presumption of a homeproduct bias in spending. From the early attempts to add international transactions to the Keynesian model [Machlup (1943), Meade (1951)], to the advent of models with perfect capital mobility [Mundell $(1963,1968)$ and Fleming (1962)], the presumption has been that foreign trade, while it exists, is a small portion of total economic activity. I follow in this tradition by investigating the effects of home bias on the transmission of monetary policy in a two-country dynamic optimizing model.

There have been models, of course, that have deviated from the presumption of home bias. In the 1970s, in models of the monetary approach to the balance of payments, traded goods produced in different countries were assumed to be perfect substitutes. More recently, individuals in the pathbreaking two-country, sticky-price dynamic optimizing model of Obstfeld and Rogoff (1995) have identical preferences for all goods, irrespective of origin.

The assumption of identical tastes simplifies the analysis but it somewhat restrictive. Identical goods preferences (and the law of one price) imply that both relative and absolute consumption-based purchasing power parity (PPP) hold at all times. Identical preferences also preclude exchange rate overshooting: interest rates, both real and nominal, are identical across countries, so uncovered interest parity (UIP) implies that after a monetary expansion the nominal exchange rate jumps immediately to its long-run level.

Allowing for a home-product bias makes the model consistent with two aspects of observed exchange rate behavior that macroeconomic models are notoriously poor at replicating: the extreme volatility of nominal exchange rates and the existence of long-run deviations from PPP. As home bias increases, Dornbusch (1976) type nominal exchange rate overshooting becomes more pronounced. In fact, I derive a condition for overshooting that is not too dissimilar from that obtained from a modified Dornbusch model. Moreover, when there is home bias, nominal exchange rates are more volatile than fundamentals such as price levels and money supplies, an empirical regularity which real business cycle models have trouble matching (see Chari, Kehoe, and McGratten (1997)).

It is not surprising that asymmetric changes in money supplies produce short-run deviations from relative PPP in a model with home bias and sticky prices. In my model, asymmetric changes in money supplies also produce small permanent movements in the real exchange rate, a result that is consistent with empirical findings. ${ }^{1}$ The explanation for this result is that the wealth transfers that accompany net foreign asset positions are spent disproportionately on domestically produced goods

\footnotetext{
1 There is vast empirical evidence that deviations from PPP exist and that convergence to PPP is a slow process (See, for example, the review of Froot and Rogoff, 1995).
} 
and, therefore, induce movements in the real exchange rate. ${ }^{2}$ In the short run, any asymmetric change in money supplies results in a current account imbalance, and hence a wealth transfer of the same magnitude. With home bias, this wealth transfer results in a large temporary change in the real exchange rate. Current accounts must be balanced in the long run, but the short-run imbalance results in a permanent net foreign asset position; monetary policy is, hence, not neutral in the long run. The interest payments on the permanent net foreign asset position represent (small) wealth transfers. With home bias, these small permanent wealth transfers result in small permanent movements in the real exchange rate and, hence, small permanent deviations from relative PPP.

This paper shows that allowing for differences in tastes across countries has important implications for welfare analysis. When preferences are identical (and initial net foreign assets are zero), a domestic monetary expansion no longer has the standard 'beggar-thy-neighbor' effect. In fact, for welfare analysis, which country expands its money supply is irrelevant: utility increases equally throughout the world. By decomposing changes in utility into two components, the expenditureincreasing effect of increased world demand and the expenditure-switching effect of an unexpected exchange rate depreciation, it becomes apparent that this result is due to the assumption of identical preferences. The expenditure-increasing effect is identical across countries and is not affected by the degree of home bias, but the expenditure-switching effect, only apparent when there is home bias, increases domestic utility at the expense of foreign utility. With strong enough home bias, the switching effect is greater in magnitude than the increasing effect and foreign utility falls. That is, with enough home bias monetary policy is beggar-thy-neighbor. Conversely, if individuals prefer imported goods, monetary policy can be beggar-thyself. Only when tastes are identical does the switching effect drop out; in this case utility in both countries depends only (and identically) on changes in world demand.

The model presented here belongs to what has been termed the 'new open economy macroeconomics' that has grown from Obstfeld and Rogoff's seminal 1995 paper; see Lane (1999) for an excellent survey. Other models, developed simultaneously, that like this one have the law of one price but obviate the assumption of identical tastes, are Ghironi (1998), which allows for biased spending habits across continents in a U.S.-Europe model, and Hau (forthcoming), which allows for nontraded goods. Both use a less general specification for real balances and therefore cannot produce exchange rate overshooting. ${ }^{3}$ In other models, the law of one price does not hold; see, for example, the pricing-to-market models of Tille (1998) and Betts and Devereux (2000). There is much empirical evidence against the law of one price (see Isard (1977) and Engel and Rogers (1996)). However, as Obstfeld and Rogoff (2000) point out, in the pricing-to-market models an exchange rate depreciation counterfactually improves a country's terms of trade. In any case, many of the conclusions from these models are similar to mine. Finally, home bias has been incorporated

\footnotetext{
${ }^{2}$ Branson and Henderson (1985) highlight the effect of wealth transfers in a setting with home bias of both assets and goods. Krugman (1990) notes the importance of capital flows and biased consumption on the equilibrium real exchange rate.

${ }^{3}$ Corsetti and Pesenti (1998), by separating the elasticity of substitution between domestic and foreign goods from the degree of monopolistic competition, are able to get closed-form solutions for a two-country dynamic optimizing model with logarithmic preferences for real balances. They assume a two-good world with identical tastes, consumption-based PPP, and unitary elasticity of substitution. Taken together these assumptions imply that current account imbalances never occur.
} 
into the numerical simulations of real business cycle theorists. Chari, Kehoe, and McGratten (1998) assume home bias, but do not spell out the implications of this assumption.

The paper is organized as follows. In Section II the dynamic optimizing model is developed. In Section III, analytical solutions, obtained by log-linearizing around an initial steady state, are discussed; a numerical example is presented; and the similarities with the Dornbusch (1976) exchange rate overshooting result are explored. The welfare implications of home bias are investigated in Section IV. Section V concludes.

\section{A Two-Country Optimizing Model with Home Bias}

In this section I develop a two-country optimizing model with home bias (II.A) and derive the steady-state (II.B) and short-run (II.C) changes used to analyze the model. Throughout I assume that the two countries are mirror images - that they are of identical sizes and have equal biases for their own domestically produced goods. ${ }^{4}$ The mirror image assumption has as a special case identical preferences but in general allows for home bias.

\section{II.A The Structural Model and Initial Steady State}

The world comprises two countries called Home and Foreign, and is inhabited by a continuum of producer/consumers each producing a single differentiated product. Prices are sticky, which, in this model with imperfect competition, may be motivated by a 'menu costs' argument as in Mankiw (1985). World population is normalized to one and individuals producer/consumers are indexed by $z \in[0,1]$, with one-half residing in Home and Foreign. There is no uncertainty except for one-time unanticipated shocks that are either temporary or permanent. Individuals in both countries can freely borrow and lend on world capital markets. The supply side of the model is based on the static closed-economy models of Blanchard and Kiyotaki (1987) and Ball and Romer (1989). For simplicity, it is assumed that output is equal to labor input. The demand side is based on a Dixit and Stiglitz (1977) type consumption index.

The problem of a typical Home resident, $z$, is presented in Table 1; the typical foreign resident's problem is analogous. A Home resident chooses paths for consumption, $C$; money and bond holdings, $M$ and $B$; and effort or output, $y(z)$, to maximize a time separable utility function with unitary elasticity of intertemporal substitution given by (T1.1). It is assumed that $\beta$, the subjective discount factor, is strictly between zero and one, and $\epsilon$, the inverse of the elasticity of substitution between consumption and real balances, is greater than zero. Importantly, the setup does not impose $\epsilon=1$, as do models that assume logarithmic preferences for real balances, and therefore does not preclude exchange rate overshooting.

Table 1: A Typical Home Producer/Consumer's Problem

\footnotetext{
${ }^{4}$ The mirror image assumption can easily be relaxed when analyzing numerical solutions.
} 


$$
\begin{aligned}
& U_{t}=\sum_{s=t}^{\infty} \beta^{s-t}\left[\log C_{s}+\frac{\chi}{1-\varepsilon}\left(\frac{M_{s}}{P_{s}}\right)^{1-\varepsilon}-\frac{\kappa_{s}}{2} y_{s}(z)^{2}\right] \\
& B_{H, t}+E_{t} B_{F, t}+M_{t}=\left(1+i_{t-1}\right) B_{H, t-1}+\left(1+i_{t-1}^{*}\right) B_{F, t-1}+M_{t-1}+p_{t}(z) y_{t}(z)-P_{t} C_{t}-P_{t} T_{t} \\
& y^{d}(z)=\frac{1}{2}\left(c_{H}(z)+c_{H}^{*}(z)\right)=\frac{1}{2}\left(\left(\frac{p(z)}{P}\right)^{-\theta} \alpha C+\left(\frac{p(z)}{E P^{*}}\right)^{-\theta}(2-\alpha) C^{*}\right)
\end{aligned}
$$

In each period $t$ a Home resident faces a budget constraint given by equation (T1.2), which takes into account costless international lending and borrowing. ${ }^{5}$ It is assumed that the government's budget is balanced each period, so increases in the money supply with no change in government spending result in lump-sum transfer payments, given by $-T_{t}$ in equation (T1.2). ${ }^{6}$ A Home producer, $z$, takes as given world demand for her product, defined as a population weighted average of Home and Foreign demands, given by equation (T1.3).

In Table 2, which shows the consumption index and demand functions for Home and Foreign goods, $p(z)$ and $p^{*}(z)$ are prices of a good $z \in[0,1 / 2]$ produced in Home and a good $\mathrm{z} \in(1 / 2,1]$ produced in Foreign, respectively; $E$ is the Home currency price of Foreign currency; $P$ is the consumer price index (CPI); and the law of one price is assumed to hold. ${ }^{7}$ Home bias is introduced through a parameter in the consumption index, equation (T2.1), which is a modification of the Dixit and Stiglitz (1977) constant elasticity of substitution form. Specifically, there is a home-good bias in consumption patterns if at given relative prices the ratio of Home goods consumed to Foreign goods consumed is higher in Home. A Home consumer's demand functions for Home and Foreign goods, equations (T2.2) and (T2.3), derived by minimizing the cost of one unit of composite consumption taking product prices as given, is shown to depend on the home bias parameter, $\alpha(\alpha \in(0,2))$, and relative prices. $^{8}$ The intratemporal substitution elasticity between Home and Foreign goods, $\theta$, is also the price elasticity of demand faced by each producer, and is assumed to be greater than one to ensure that marginal revenue is positive.

5 The stocks of Home and Foreign bonds held by Home residents entering period $t+1$ is $B_{H, t}$ and $B_{F, t}$, respectively. The nominal interest rates, $i_{t}$ and $i_{t}{ }^{*}$, are defined as the interest rates earned between $t$ and $t+1$. The zero net bond condition imposes $B_{t}+E_{t} B_{t}^{*}=0$, where $B_{t}=B_{H, t}+E_{t} B_{F, t}$ and $B_{t}^{*}=B_{H, t}^{*} / E_{t}+B_{F, t}^{*}$.

6 More generally, $T_{t}$ represents lump-sum taxes. See Warnock (1999) for an analysis of the effects of balanced-budget government spending in this setup.

${ }^{7}$ The price index may be interpreted as the minimum cost of one unit of consumption and is given by

$$
P=\left(\int_{0}^{n} \alpha p(z)^{1-\theta} d z+\int_{n}^{1}(2-\alpha)\left[E p^{*}(z)\right]^{1-\theta} d z\right)^{\frac{1}{1-\theta}}
$$

See Obstfeld and Rogoff (1996), pages 222-228, for a complete description of price indices.

8 The range for $\alpha$ was chosen to nest Obstfeld and Rogoff (1995). Any other non-negative range can be used without affecting the dynamics of the model, but would affect the initial steady-state levels. 
Table 2. A Home Consumer's Consumption Index

$$
\begin{aligned}
& C=\left[\int_{0}^{1 / 2} \alpha^{1 / \theta}\left(c_{H}(z)\right)^{\frac{\theta-1}{\theta}} d z+\int_{1 / 2}^{1}(2-\alpha)^{1 / \theta}\left(c_{F}(z)\right)^{\frac{\theta-1}{\theta}} d z\right]^{\frac{\theta}{\theta-1}} \\
& c_{H}(z)=\alpha(p(z) / P)^{-\theta} C, \quad z \in[0,1 / 2] \\
& c_{F}(z)=(2-\alpha)\left[\frac{E p^{*}(z)}{P}\right]^{-\theta} C, \quad z \in(1 / 2,1]
\end{aligned}
$$

From Table 2, the relative demand of a Home consumer for Home goods is

$$
\frac{c_{H}}{c_{F}}=\left(\frac{\alpha}{2-\alpha}\right)\left(\frac{p}{E p^{*}}\right)^{-\theta}
$$

where $p$ and $p^{*}$ are the prices of the typical Home and Foreign good, respectively. ${ }^{9}$ If $\alpha>1$, there is a home bias in consumption; that is, for any given relative price, Home consumers will always demand relatively more Home goods than will Foreign consumers. This does not imply Home consumers will always demand more Home than Foreign goods: with high enough relative prices a Home consumer, even with a home bias, will demand more imported than domestic goods.

Home bias is shown graphically in Figure 1, which depicts the effect of home bias on a consumer's choice between domestic and imported goods and is drawn for unitary relative prices. Utility curve $\mathrm{u}_{\mathrm{A}}$ and income-consumption path OA represents the case in which consumers have identical preferences for all goods regardless of origin: with unitary relative prices, consumers demand equal amounts of domestic and imported goods. Consumers with a home bias ( $\alpha=1.6$ in this case) have utility curve $\mathrm{u}_{\mathrm{B}}$ and income-consumption path $\mathrm{OB}$; with unitary relative prices their relative demand for domestic goods is $\alpha /(2-\alpha)$, or four.

The first-order conditions from a typical Home individual's dynamic maximization problem are given in Table 3; Foreign individuals have analogous first-order conditions. Equation (T3.1) is the standard first-order consumption Euler equation for unitary elasticity of intertemporal substitution. The consumption-based money demand equation, (T3.2), equates the marginal utility of real balances to the opportunity cost in terms of consumption, and reflects the fact that at the margin in period $t$ individuals must be indifferent between consuming one unit of $C$ and using the same funds to raise cash balances. Equation (T3.3) is the labor-leisure tradeoff: the marginal utility of the additional revenue earned from producing an extra unit of the Home good must equal the marginal disutility of the needed effort. Equation (T3.4) is a real uncovered interest parity condition - both real and nominal uncovered interest parity hold in this perfect foresight model - that captures the

9 Since all individuals in a country are symmetric and choose the same price and output in equilibrium, the $z$ denotation can be dropped. The price and output of the typical Home good are denoted by $p$ and $y$, respectively. 
dynamics of the real exchange rate, $Q_{t}$, defined as $\mathrm{E}_{\mathrm{t}} \mathrm{P}_{\mathrm{t}}{ }^{*} / \mathrm{P}_{\mathrm{t}}{ }^{10}$ (As defined, an increase in $Q$ is a real depreciation for the Home currency.)

Table 3: First-Order Conditions

$$
\begin{aligned}
C_{t+1} & =\beta C_{t}\left(1+r_{t}\right) \\
\frac{M_{t}}{P_{t}} & =\left[\chi C_{t} \frac{1+i_{t}}{i_{t}}\right]^{1 / \varepsilon} \\
y_{t}^{\theta+1} & =\left(\frac{\theta-1}{\theta \kappa_{t}}\right)^{\theta} C_{t}^{-\theta}\left[n \alpha C_{t}+(1-n)\left(2-\alpha^{*}\right)\left(\frac{E_{t} P_{t}^{*}}{P_{t}}\right)^{\theta} C_{t}^{*}\right] \\
1+r_{t} & =\frac{Q_{t+1}}{Q_{t}}\left(1+r_{t}^{*}\right)
\end{aligned}
$$

Steady-state relations are presented in Table 4. In solving for the steady state it is assumed that all exogenous variables are constant. This, in turn, implies a constant steady-state consumption level, which, by the consumption Euler, equation (T3.1), implies a constant steady-state real interest rate, given by equation (T4.1). In the steady state the intertemporal budget constraints are given by equations (T4.2) and (T4.2*). It is assumed in the initial steady state net foreign assets are zero. ${ }^{11}$ From (T4.2) and (T4.2*), in the initial steady state consumption equals output, and is given by (T4.3), which follows from the labor-leisure tradeoff (T3.3). Initial steady state real balances are given by equation (T4.4).

10 The Home real interest rate and nominal UIP condition in this perfect foresight model are given by

$$
1+i_{t}=\frac{P_{t+1}}{P_{t}}\left(1+r_{t}\right) \quad \text { and } \quad 1+i_{t}=\frac{E_{t+1}}{E_{t}}\left(1+i_{t}^{*}\right) .
$$

${ }^{11}$ Note that the mirror image assumption and the assumptions made to get an initial, closed form steady state together imply that $\bar{p}_{0}=\bar{E}_{0} \bar{p}_{0}^{*}, \bar{p}_{0}=\bar{P}_{0}$ and $\bar{p}_{0}^{*}=\bar{P}_{0}^{*}$. 
Table 4: Steady State Relations

$$
\begin{aligned}
& \bar{r}=\frac{1-\beta}{\beta} \\
& \bar{C}=\bar{r} \bar{B}+\frac{\bar{p} \bar{y}}{\bar{P}} \\
& \bar{C}^{*}=-\frac{\bar{r} \bar{P} \bar{B}}{\bar{E} \bar{P}^{*}}+\frac{\bar{p}^{*} \bar{y}^{*}}{\bar{P}^{*}}
\end{aligned}
$$

Initial Steady State Assumption

$$
\bar{B}_{0}=\bar{B}_{0}^{*}=0
$$

Initial Steady State Levels

$$
\begin{aligned}
& \bar{y}_{0}=\bar{y}_{0}^{*}=\left(\frac{\theta-1}{\theta \bar{\kappa}}\right)^{1 / 2}=\bar{C}_{0}=\bar{C}_{0}^{*} \\
& \frac{\bar{M}_{0}}{\bar{P}_{0}}=\frac{\bar{M}_{0}^{*}}{\bar{P}_{0}^{*}}=\left(\frac{\chi}{1-\beta}\right)^{1 / \varepsilon} \bar{y}_{0}{ }^{1 / \varepsilon}=\left(\frac{\chi}{1-\beta}\right)^{1 / \varepsilon} \bar{C}_{0}{ }^{1 / \varepsilon}
\end{aligned}
$$

\section{The Nature of Shocks and Price Stickiness}

To analyze the effects of changes in money supplies on Home and Foreign variables, the model is linearized around the initial steady state. The shocks are level shifts that occur in period $t$ and are either temporary (lasting one period) or permanent. In the policy experiments conducted in this paper, one-time unanticipated shocks to the money supply push the economy to a new steady state.

Price stickiness is introduced by assuming producers must set their prices before they observe the shock: for the first period of a shock, $t$, product prices are constant, but thereafter, in periods $t+1$ and beyond, product prices fully adjust and a new steady state is reached. There are, thus, two types of deviations from the initial steady state. Long-run deviations are those consistent with flexible product prices and are changes from the initial to a new steady state. These long-run steady-state changes are denoted by tildes; for any variable $X, \tilde{X} \equiv d \bar{X} / \bar{X}_{0}$, where $\bar{X}_{0}$ is the initial steady-state value. In the short run when product prices are fixed, the economies are not on a steady-state path. Short-run deviations from the initial steady state are denoted by hats; for any variable $X$, $\hat{X} \equiv d X_{t} / \bar{X}_{0}$, where $t$ is the period of the shock.

\section{II.B Long-Run Steady-State Changes}

Long-run equations for cross-country differences are presented in Table 5. Log-linearizing the Home CPI -- found in footnote 7 -- and its Foreign counterpart around the initial steady state, and 
using the definitions of the real exchange rate and terms of trade, $\tau$, yields equation (T5.1). ${ }^{12}$ When preferences are identical $(\alpha=1)$, the long-run real exchange rate is constant and PPP holds regardless of the shock. The log-linearized versions of (T1.3) and its Foreign counterpart, interpreted as world demand schedules for typical home and foreign products, give equation (T5.2). From equation (T5.2), it is clear how the bias parameter, $\alpha$, affects relative demand. With home bias spending differentials and changes in the terms of trade affect demand. Spending differentials matter more as home bias becomes more pronounced, and not at all if tastes are identical across countries. The terms of trade influences demand less as $\alpha$ increases: if citizens have an inherent preference for domestic goods, relative prices matter somewhat less.

Table 5: Long-Run Equations - Cross-Country Differences

$$
\begin{aligned}
& \tilde{Q}=(1-\alpha) \tilde{\tau} \\
& \tilde{y}-\tilde{y}^{*}=-\alpha(2-\alpha) \theta \tilde{\tau}+(\alpha-1)\left(\tilde{C}-\tilde{C}^{*}\right) \\
& (\theta+1)\left(\tilde{y}-\tilde{y}^{*}\right)=(\alpha-\theta-1)\left(\tilde{C}-\tilde{C}^{*}\right)-(2-\alpha)(\alpha-1) \theta \tilde{\tau} \\
& \left(\tilde{C}-\tilde{C}^{*}\right)=\frac{2 \bar{r} d \bar{B}}{\bar{y}}+(2-\alpha) \tilde{\tau}+\left(\tilde{y}-\tilde{y}^{*}\right) \\
& \tilde{C}-\tilde{C}^{*}=\left(\hat{C}-\hat{C}^{*}\right)+(\tilde{Q}-\hat{Q}) \\
& \left(\tilde{M}-\tilde{M}^{*}\right)-\left(\tilde{P}-\tilde{P}^{*}\right)=\frac{1}{\varepsilon}\left(\tilde{C}-\tilde{C}^{*}\right)
\end{aligned}
$$

Linearized versions of equation (T3.3) and its foreign counterpart, which describe the optimal flexible-price output levels, give equation (T5.3), which shows that long-run supply differentials are affected by differences in consumption and - as long as preferences are not biased - changes in the terms of trade. An increase in relative consumption makes Home individuals want to enjoy relatively more leisure, thus relative supply falls. An improvement in Home terms of trade reduces relative supply if $\alpha>1$.

Linearizing (T4.2) and (T4.2*), the intertemporal budget constraints, around the initial steady state yields equation (T5.4), an equation for long-run cross-country consumption differentials. The effect of changes in the terms of trade on consumption differentials is maximum when $\alpha=1$ : relative income changes matter most when imported goods carry heavy weights in the consumption basket. Subtracting the log-linearized versions of consumption Euler equations, (T3.1) and its foreign counterpart, yields equation (T5.5), which provides one link between the short and long runs, and shows that consumption differentials are permanent after a shock only if the real exchange rate is constant.

Subtracting the long-run linearized versions of the money demand equations (T4.4) and its foreign counterpart gives equation (T5.6), which uses the fact that across steady states real interest rates and inflation rates do not change. Note that money demand depends on consumption, as in many other intertemporal monetary models. If $\epsilon=1$, the long-run change in relative consumption equals the

\footnotetext{
12 An increase in $\tau$, which is defined as $\mathrm{p} / \mathrm{p} * \mathrm{E}$, represents an improvement in Home's terms of trade.
} 
long-run change in relative real balances; in the more general case of $\epsilon>1$, the change in relative consumption is greater than the change in real balances.

\section{II.C. Short-Run Deviations from the Initial Steady State}

Cross-country differences of short-run deviations from the initial steady state are presented in Table 6. In the short run nominal product prices, $p$ and $p^{*}$, are fixed, so changes in CPIs depend solely on changes in the exchange rate. Equation (T6.1) highlights two implications of home bias for exchange rates: as home bias increases, the correlation between real and nominal exchange rates increases, and nominal exchange rates become much more volatile than price indices. ${ }^{13}$

Table 6: Short-Run Equations - Cross-Country Differences

$$
\begin{aligned}
& \hat{Q}=(\alpha-1) \hat{E} \\
& \hat{y}-\hat{y}^{*}=\alpha(2-\alpha) \theta \hat{E}+(\alpha-1)\left(\hat{C}-\hat{C}^{*}\right) \\
& \hat{C}-\hat{C}^{*}=-\frac{2 d \bar{B}}{\bar{y}_{0}}+\left(\hat{y}-\hat{y}^{*}\right)-(2-\alpha) \hat{E} \\
& \left(\hat{M}-\hat{M}^{*}\right)-(2-\alpha) \hat{E}=\frac{1}{\varepsilon}\left(\hat{C}-\hat{C}^{*}\right)-\frac{1}{\bar{r} \varepsilon}(\tilde{E}-\hat{E}) \\
& \hat{r}-\hat{r}^{*}=\frac{\tilde{Q}-\hat{Q}}{1-\beta}
\end{aligned}
$$

With preset prices, the equations equating marginal revenue and marginal cost, (T3.3), need not hold; short-run output is demand-determined and short-run output differentials are given by equation (T6.2). As in the long run, spending differentials affect output differentials only if there is home bias and more spending stays at home. Note, too, that the demand-switching effect of nominal exchange rate changes is maximum when $\alpha=1$ and decreases as $\alpha$ increases.

Equations for Home and Foreign current accounts yield equation (T6.3), which shows the saving (or borrowing) that arise from imbalances in consumption and output. ${ }^{14}$ Log-linearizing the money demand equations, (T3.2) and its foreign counterpart, and noting that all (t+1) subscripts are steadystate changes (tildes) and all $t$ subscripts are short-run changes (hats), gives equation (T6.4), which

\footnotetext{
${ }^{13}$ To see that the nominal exchange rate is more volatile than relative prices when there is home bias, note that (T6.1) implies that $\hat{P}-\hat{P}^{*}=(2-\alpha) \hat{E}$. If $\alpha=1.8$, nominal exchange rate changes are five times greater than changes in relative prices. MacDonald (1988) provides empirical evidence of this.

14 The short-run Home current account surplus is

$$
B_{t}-B_{t-1}=r_{t-1} B_{t-1}+p_{t} y_{t} / P_{t}-C_{t}
$$

This is the amount lent to Foreign in the short run, which is repaid with interest in the long run when current accounts are required to be balanced. The change in net foreign assets in equation (T6.3) is a long-run steady-state change because in the special case of an initial steady state with zero net foreign assets, the short-run and long-run changes in the net foreign asset position are identical.
} 
shows the relationship between the short-run real interest rate differential and real exchange rate dynamics. Equation (T6.5), a real interest parity condition, shows the relationship between real interest rate differentials and real exchange rate dynamics.

\section{The Dynamic Responses to Monetary Shocks}

In this section I consider an unexpected permanent monetary shock. The equations that form the basis for solving the model -- long-run semi-reduced form equations and the MM and GG schedules -- are presented in Section III.A, along with a graphical example. Analytical solutions are discussed in Section III.B, and a numerical example is presented in Section III.C. The similarities with the Dornbusch (1976) exchange rate overshooting result are explored in Section III.D.

\section{III.A. Long-Run Semi-Reduced Form Equations and the MM and GG Curves}

Table 7 contains cross-country differences of long-run semi-reduced form equations that hold for monetary shocks and can be used to examine the effects of net foreign asset shocks on relative consumption (T7.1), relative output (T7.2) and the terms of trade (T7.3). ${ }^{15}$ Although care must be taken when interpreting these partial relationships, some intuition can be gleaned from them. Equation (T7.1) shows that a wealth transfer increases relative consumption, but by less than the change in relative net foreign asset positions: Home individuals take advantage of the increased wealth to both increase consumption and reduce their work effort. From equation (T7.3), an increase in Home relative consumption, caused perhaps by a wealth transfer, enables Home individuals to work less and increases the long-run relative price of Home products (the terms of trade).

Table 7: Long-Run Semi-Reduced Forms - Cross-Country Differences

$$
\begin{aligned}
& (1-\alpha+\theta)\left(\tilde{C}-\tilde{C}^{*}\right)=\theta(2-\alpha) \tilde{Q}+(\theta+1) \frac{\bar{r} d \bar{B}}{\bar{y}_{0}} \\
& (1+\theta)\left(\tilde{y}-\tilde{y}^{*}\right)=-(\theta+1-\alpha)\left(\tilde{C}-\tilde{C}^{*}\right)-(2-\alpha)(\alpha-1) \theta \tilde{\tau} \\
& \tilde{\tau}=\frac{\alpha\left(\tilde{C}-\tilde{C}^{*}\right)}{(2-\alpha)(\alpha \theta+1)}=\frac{-\alpha\left(\tilde{y}-\tilde{y}^{*}\right)}{(2-\alpha)(1-\alpha+\alpha \theta)}
\end{aligned}
$$

15 To derive the equations in Table 7, equate demand and supply for both Home and Foreign to get the following equations:

$$
(\alpha-2 \theta) \tilde{C}+(2-\alpha) \tilde{C}^{*}+\theta(2-\alpha) \tilde{Q}=-(\theta+1) \frac{\bar{r} d \bar{B}}{\bar{y}_{0}} ; \quad(\alpha-2 \theta) \tilde{C}^{*}+(2-\alpha) \tilde{C}-\theta(2-\alpha) \tilde{Q}=(\theta+1) \frac{\bar{r} d \bar{B}}{\bar{y}_{0}}
$$

Solving the above two equations simultaneously gives semi-reduced form equations for consumption; semi-reduced form equations for output are derived analogously. 
Table 8 contains the equations for the $\mathbf{M M}$ and $\mathbf{G G}$ curves, which show relationships between shortrun changes in the nominal exchange rate and relative consumption. The MM curve, which is obtained using equations (T5.6) and (T6.4), shows how relative consumption changes, through their effect on relative money demand, affect the exchange rate. The GG curve, equation (T8.2), obtained using equations (T6.2), (T6.3), and (T7.1), shows the currency depreciation - and therefore the increase in relative output - needed to justify an increase in relative consumption. ${ }^{16}$ Definitions for the $\gamma_{\mathrm{i}}$ in Table 8 are in the appendix.

Table 8: MM and GG Curves

(MM)

$$
\begin{aligned}
& \hat{E}=-\frac{\gamma_{0}(1+\bar{r} \varepsilon)+\alpha \gamma_{2}}{\gamma_{0} \gamma_{1}+\alpha(1-\alpha) \gamma_{2}}\left(\hat{C}-\hat{C}^{*}\right)+\frac{\gamma_{0}(1+\bar{r} \varepsilon) \varepsilon}{\gamma_{0} \gamma_{1}+\alpha(1-\alpha) \gamma_{2}}\left(\tilde{M}-\tilde{M}^{*}\right) \\
& \hat{E}=\frac{\gamma_{0}\left(\gamma_{3}+\gamma_{5}\right)-\alpha \gamma_{4}}{\alpha(1-\alpha) \gamma_{4}+\gamma_{0} \gamma_{6}}\left(\hat{C}-\hat{C}^{*}\right)
\end{aligned}
$$

The MM and GG curves are shown graphically in Figure 2. From equations (T8.1) and (T8.2), as $\alpha$ increases (or $\epsilon$ increases or $\theta$ decreases), the $\mathbf{M M}$ curve becomes steeper; when there is home bias consumer prices are relatively insulated, so an increase in relative consumption has a greater effect on relative real balances and therefore a greater effect on the exchange rate. The GG curve flattens as $\alpha($ or $\theta)$ increases; as preferences become more biased, the expenditure switching effect is greater and relative consumption increases more for a given depreciation.

The short-run effects of a permanent increase in relative money supply $\left(\hat{M}-\hat{M}^{*}=\tilde{M}-\tilde{M}^{*}>0\right)$ on the nominal exchange rate and relative consumption are shown graphically in Figure 2, which shows that when preferences are biased towards domestically produced goods, a given increase in relative money supply leads to a larger exchange rate depreciation and a larger change in relative consumption. The initial equilibrium in Figure 2 is at the origin: absent a policy shock the exchange rate and consumption differential are constant. From equation (T8.1), the vertical intercept of the MM curve is the amount of the permanent increase in the relative money supply, $\tilde{M}-\tilde{M}^{*}$, if preferences are identical, but is greater than $\tilde{M}-\tilde{M}^{*}$ when there is home bias. Thus, in this model the nominal exchange rate is more volatile than relative money supplies except when there is no home bias. Moreover, since the GG curve is flatter as preferences become more biased towards domestic goods, relative consumption increases more.

\section{III.B. Analytical Solutions}

It is straightforward to solve the model for country levels after first solving for cross-country differences and world weighted averages. To solve for cross-country differences, use the $\mathbf{M M}$ and GG curves to get solutions for $\hat{E}$ and $\hat{C}-\hat{C}^{*}$, which can then be used in equation (T6.2) to get

${ }^{16}$ Note that in order to incorporate long-run changes of the real exchange rate into the curves, equations (T5.5) and (T7.3) are also used in the derivations. 
$\hat{y}-\hat{y}^{*}$ and in equation (T6.3) to get $d \bar{B} / \bar{y}_{0}$. Armed with $d \bar{B} / \bar{y}_{0}$, Table 7 yields long-run solutions.

Table 9 provides world weighted averages for an unexpected permanent change in world money supply. ${ }^{17}$ Long-run world neutrality of money holds: in the long-run, world money supply determines world price levels (T9.2) but does not affect world output or consumption (T9.1). Equations (T9.3) and (T9.4) - derived using a world consumption Euler, $\tilde{C}^{W}=\hat{C}^{W}+(1-\beta) \hat{r}^{W}-$ show the importance of the interest elasticity of money demand, approximately equal to $1 / \epsilon$, in determining the magnitude of short-run changes in real variables. As money demand becomes more interest inelastic (i.e., as $\in$ increases), real interest rates fall more -- and, hence, demand and output increase more -- for a given increase in world money supply.

Table 9: Money Supply Shock: World Weighted Averages

$$
\begin{aligned}
& \tilde{y}^{W}=\tilde{C}^{W}=0 \\
& \tilde{P}^{W}=\tilde{M}^{W} \\
& \hat{y}^{W}=\hat{C}^{W}=\frac{1+\bar{r} \varepsilon}{1+\bar{r}} \tilde{M}^{W} \\
& \hat{r}^{W}=-\frac{1+\bar{r} \varepsilon}{\bar{r} \beta(1+\bar{r})} \tilde{M}^{W}
\end{aligned}
$$

Analytical solutions for country levels are given in the appendix. For ease of exposition I will discuss only the case of a permanent increase in the Home money supply, although solutions are written for any permanent change in relative money supplies. The $\gamma_{\mathrm{i}}$ in the expressions that follow are also given in the appendix.

\section{Short-Run Solutions: The Expenditure-Increasing and Expenditure-Switching Effects}

Short-run changes are most easily expressed as the sum of two components, the expenditureincreasing effect of a change in world demand, $\hat{C}^{W}$, given by equation (T9.3), and the expenditureswitching effect of a change in the nominal exchange rate, $\hat{E}$, given by

$$
\hat{E}=\frac{\varepsilon(1+\bar{r} \varepsilon) \gamma_{0} \gamma_{10}}{\gamma_{11}}\left(\tilde{M}-\tilde{M}^{*}\right)
$$

For a given increase in Home money supply, the nominal exchange rate depreciates more the greater is the degree of home bias; when imported goods carry little weight in consumption baskets, consumer prices are insulated and the exchange rate must adjust more. Solutions for short-run changes in real Home variables are presented in Table 10. For short-run changes in Foreign

${ }^{17}$ The world weighted average for any variable $X$ is given by $X_{t}^{W}=\frac{1}{2} X_{t}+\frac{1}{2} X_{t}^{*}=\frac{1}{2}\left(X_{t}+X_{t}^{*}\right)$. 
variables, the expenditure-increasing effects of increased world demand are identical to Home's, but the expenditure-switching effects have the opposite sign.

Table 10: The Short-Run Real Effects of Changes in World Demand and Relative Prices

$$
\begin{aligned}
& \hat{C}=\hat{C}^{W}+\hat{E} \frac{\gamma_{8}}{2 \gamma_{10}} \\
& \hat{y}=\hat{C}^{W}+\hat{E} \frac{\alpha(2-\alpha) \theta \gamma_{10}+(\alpha-1) \gamma_{8}}{2 \gamma_{10}} \\
& \hat{r}=-\frac{\hat{C}^{W}}{\beta}-\hat{E}(\alpha-1) \frac{2 \gamma_{10} \gamma_{13}+\alpha \bar{r}(\theta+1) \gamma_{12}}{4 \bar{r} \beta \gamma_{10} \gamma_{13}}
\end{aligned}
$$

For Home consumption, equation (T10.1), the expenditure-switching effect increases with $\alpha$; as home bias increases, a smaller portion of Home's consumption basket becomes more expensive, and Home residents are able to increase consumption even more. Similarly, a smaller portion of Foreign's consumption basket becomes cheaper, so Foreign residents cannot increase consumption as much. For Home output, equation (T10.2), the expenditure-switching effect is maximum when preferences are identical; an exchange rate depreciation has the greatest effect on demand for Home goods when they figure prominently in Foreign consumption baskets. For plausible parameter values, the switching effect on output is greater than the effect of increased world demand, so Foreign output falls. Finally, for the Home real interest rate, equation (T10.3), when preferences are identical there is no switching effect, thus the drop in real interest rates is identical across countries. The switching-effect on real interest rates becomes greater as home bias increases, causing Home's real interest rate to fall more, and Foreign's to fall less.

\section{Long-Run Solutions: The Role of Wealth Transfers}

Long-run changes in real variables are easily expressed as functions of the permanent wealth transfer associated with the interest payments on the net foreign asset position, which is given by

$$
\frac{\bar{r} d \bar{B}}{\bar{y}_{0}}=\left(\tilde{M}-\tilde{M}^{*}\right) \frac{(1-\alpha / 2) \bar{r} \varepsilon(1+\bar{r} \varepsilon) \gamma_{0} \gamma_{12}}{\gamma_{11}}
$$

Current account imbalances and the associated wealth transfers are greater when there is a large disparity in output, which, from the discussion in the previous section, occurs when home bias is small. When home bias is severe, current account imbalances are small because the drop in import prices does not induce sufficient purchases. Long-run changes in output, consumption, and the real exchange rate are presented in Table 11.

Table 11: The Long-Run Real Effects of Wealth Transfers 


$$
\begin{aligned}
& \tilde{y}=-\tilde{y}^{*}=-\frac{\bar{r} d \bar{B}}{2 \bar{y}_{0}} \\
& \tilde{C}=-\tilde{C}^{*}=\frac{\bar{r} d \bar{B}}{2 \bar{y}_{0}} \frac{\alpha \theta+1}{1+\alpha(\theta-1)} \\
& \tilde{Q}=-\frac{\bar{r} d \bar{B}}{2 \bar{y}_{0}} \frac{\alpha(\alpha-1)}{(2-\alpha)(1+\alpha(\theta-1))}
\end{aligned}
$$

The wealth transfer associated with a net foreign asset position enables Home residents to work less, equation (T11.1), and consume more, equation (T11.2), than their Foreign counterparts. Along the lines of Krugman (1990), when preferences are biased the permanent wealth transfer is spent disproportionately on domestic goods, inducing a small permanent change in the real exchange rate, equation (T11.3). From equation (T5.1), Home's terms of trade improves in the long run.

\section{III.C. Numerical Solutions}

Figures 3(a) - 3(i) show, for different degrees of home bias, the effect of a one-percent permanent increase in Home money supply. In each graph in Figure 3, the scale on the x-axis is 100 times $\alpha$; that is, $\alpha=1$ is at the tick mark labeled ' 100 ' and $\alpha$ varies from 0.01 to 1.99 along the entire $\mathrm{x}$-axis. Units for $y$-axes are percent changes in the indicated variables. Parameters other than $\alpha$ are fixed at levels taken from the literature $(\theta=6, \epsilon=9$, and $\beta=0.95)$; see Sutherland (1996).

A permanent Home monetary expansion causes a short-run nominal exchange rate depreciation (Figure 3(a)). As is discussed in greater detail in the following section, if there is home bias, and as long as the consumption elasticity of money demand is not equal to 1 , the short-run depreciation exceeds the long-run depreciation and is larger than the change in money supply; that is, Dornbuschtype overshooting occurs, and the overshooting is greater the greater is home bias. The expenditureswitching effect of the short-run depreciation results in a sharp, temporary increase in Home output (Figure 3(g)). Movements in consumption are much less pronounced (Figure 3(g)), because consumption is smoothed by running a current account surplus (Figure 3(e)). Since product prices are fixed in the short-run and, hence, short-run changes in CPIs are determined solely by the share of imported goods in total expenditure and the change in the exchange rate, greater home bias implies less short-run movement in CPIs (Figure 3(d)).

The short-run current account surplus results in a permanent net foreign asset position that is the key to the long-run non-neutrality of money in this model. As was shown in Table 11, the interest payments on the net foreign asset position - and, to some extent, the degree of home bias determine the (small) long-run changes in output (Figure 3(i)) and consumption (Figure 3(h)). The degree of home bias plays a much more important role in determining the path the real exchange rate takes: if preferences are biased, the small permanent wealth transfers are spent disproportionately on domestic goods, resulting in small permanent deviations from PPP that increase with home bias (Figure 3(b)). In the long run, consumer prices are little affected by the degree of home bias (Figure $3(\mathrm{~d}))$. 
The results described in this section are reassuringly familiar. The effects of monetary policy in the dynamic optimizing model with home bias are not dissimilar to those of Mundell and Fleming. This should not be too surprising, for the reduced-form equations postulated in ad hoc models are very similar to the first-order conditions derived in optimizing models.

\section{III.D A Note on Exchange Rate Overshooting}

As shown in the numerical example, exchange rate overshooting can occur when there is home bias. In this section, I show that the condition for overshooting is very similar to that obtained from a slightly modified version of the Dornbusch (1976) model.

Figures $4 \mathrm{a}$ and $4 \mathrm{~b}$ show that in my model whether exchange rate overshooting occurs depends on preferences and the consumption elasticity of money demand $(1 / \epsilon)$. As the figures show, both identical tastes and logarithmic preferences for real balances (that is, unitary consumption elasticity of money demand) preclude exchange rate overshooting. As long as $\epsilon>1$, increasing the degree of home bias increases the overshooting. Similarly, as long as there is home bias, increasing $\epsilon$ increases overshooting. This is evident in the following expression, derived from equations (T5.1), (T5.5), (T5.6), and (T6.1).

$\hat{E}=\tilde{E} \frac{1+\bar{r} \varepsilon}{1+\bar{r}(\alpha-1+\varepsilon(2-\alpha))}+\bar{r}(\varepsilon-1)(\alpha-1) \tilde{t}$

If tastes are identical $(\alpha=1)$, or the consumption elasticity of money demand is unitary $(\epsilon=1)$, the coefficients on $\tilde{E}$ and $\tilde{t}$ are one and zero, respectively, thus $\hat{E}=\tilde{E}$ and the exchange rate jumps immediately to its long-run level. Short-run interest rates, both real and nominal, differ across countries only when there is home bias and the consumption elasticity of demand is not equal to 1 . Thus, by uncovered interest parity conditions, exchange rate overshooting, both real and nominal, can only occur when preferences are biased.

A similar condition can be derived from a version of the Dornbusch (1976) model with the following modifications. In the goods market, allow a short-run supply response, as Dornbusch does in the appendix. In the money market, start with a money demand equation in which money balances are deflated by the CPI instead of the price of domestic output and the activity variable is output in terms of consumption units. Specifically, using the notation of Dornbusch, start with the following money demand equation:

$$
\frac{M}{Q}=\left(\frac{P Y}{Q}\right)^{\varphi} \exp (-\lambda r)
$$

where the CPI , Q, consists of both domestic and imported goods (with weights $\alpha$ and 1- $\alpha$, respectively); $\mathrm{Y}$ is real output; $\mathrm{P}$ is the price of domestic output; $\mathrm{r}$ is the interest rate; and $\phi$ and $\lambda$ are the income and interest rate elasticities of money demand, respectively. 
Given these modifications - made to as easily as possible bridge the gap between Dornbusch's framework and the current framework - the condition for exchange rate overshooting is

$\frac{\alpha(1-\varphi)}{\varphi}>\mu \delta-1$

where and $\mu \delta$ is the elasticity of equilibrium output with respect to the exchange rate. Since the exchange rate elasticity of output is likely greater than 1 , the right-hand side is greater than zero. Hence, unit income elasticity of money demand $(\phi=1)$ also precludes overshooting in this modified Dornbusch model. If $\phi<1$, which corresponds to $\epsilon>1$ in my model, overshooting becomes more likely the greater is the expenditure share of domestic goods, or, equivalently, the greater is the home bias. In both the modified Dornbusch model and my model, exchange rate undershooting requires that the monetary expansion result in an increase in relative interest rates, a counterfactual condition.

A comment on the parameter, $\epsilon$, is in order. The preferences used in this model are such that $\epsilon$ determines both the consumption elasticity and the interest elasticity of money demand. Empirical estimates put the consumption elasticity of money demand at or below 1 (see Mankiw and Summers (1986)), while the interest elasticity of money demand is estimated to be closer to 0.1 (see Koenig (1990)). Thus, for example, if $\epsilon$ is chosen based on estimates of the consumption elasticity, the interest elasticity is too high. ${ }^{18}$ To date in the literature, those who have not imposed logarithmic preferences for real balances have presumed $\epsilon>1 .^{19}$

\section{The Welfare Effects of Monetary Policy}

Does expansionary monetary policy have adverse effects abroad? Recently, models based on an explicit utility function, well-suited to analyze the welfare effects of policy changes, have cast doubt on the standard result of beggar-thy-neighbor monetary policy. A rather surprising result from Obstfeld and Rogoff (1995), henceforth OR, is that the source of expansionary monetary policy does not matter: utility increases by the same amount in both countries, independent of which country actually inflates. In Corsetti and Pesenti (1998), henceforth CP, the source of expansionary monetary policy does indeed matter. In their model, expansionary Home monetary policy increases Foreign welfare and has an ambiguous effect on Home welfare; monetary policy may well be beggar-thyself. In this section I show that the model with home-product bias presented here can be used to make some sense of these recent findings.

The results of $\mathrm{CP}$ and $\mathrm{OR}$ are somewhat difficult to compare because the models differ in important ways. Due to differences in utility functions and consumption indices, monetary policy is neutral in the long run in $\mathrm{CP}$, but not in OR. As discussed above, the key to the non-neutrality of money is current account transfers and their concomitant international redistribution of wealth. In the CP

18 This point is also made by Betts and Devereux (2000).

19 See Sutherland (1996), who uses estimates from Hairault and Portier (1993), and Obstfeld and Rogoff (1995, pg.645). 
model, due to a Cobb-Douglas consumption index, perfectly competitive goods markets, and the assumption of identical preferences, real income is constant and thus there is no incentive to lend or borrow. Without the wealth transfers associated with current account imbalances, monetary policy shocks do not have real effects in the long run and, hence, do not affect long-run utility.

With this in mind, the results of $\mathrm{CP}$ and $\mathrm{OR}$ are quite similar. In both models the short-run effect of expansionary monetary policy is a decrease in relative utility, due to a greater increase in relative effort than relative consumption. The results differ because the current account imbalances that are absent from the CP model play a prominent role in the OR model. Money has real long-run effects in the OR model, and due to the assumption of identical preferences, long-run changes in relative utility exactly offset short-run changes.

Is it necessarily the case that allowing for current account imbalances neutralizes the cross-country utility effects of monetary policy? Not at all. OR suggest in a footnote (see Obstfeld and Rogoff (1995), page 648) that relaxing the assumption of zero international debt in the initial steady state would make possible differential international utility effects: a monetary expansion would result in increased utility in the debtor country and decreased utility for the creditor. Unfortunately, allowing for non-zero initial international debt means giving up closed-form solutions. I show below, though, that with home-product bias the origin of the monetary expansion matters for relative utility, and closed-form solutions do not have to be sacrificed.

The OR result that the origin of monetary policy is immaterial hinges crucially on the assumption of identical preferences. The Home utility function, equation (T1.1), gives an expression for the infinite-period discounted sum of changes in utility (disregarding liquidity effects) due to changes in consumption and output :

$$
d U=d U_{t}+d \bar{U}=\hat{C}-\kappa y_{0}^{2} \hat{y}+\frac{\beta}{1-\beta}\left(\tilde{C}-\kappa y_{0}^{2} \tilde{y}\right)=\hat{C}-\frac{\theta-1}{\theta} \hat{y}+\frac{\tilde{C}}{\bar{r}}-\frac{\theta-1}{\bar{r} \theta} \tilde{y}
$$

where the last equality uses equations (T4.1) and (T4.3). Rewriting the above expression in terms of the expenditure-shifting and expenditure-switching effects gives the following:

$$
\begin{aligned}
& d U=\frac{\hat{C}^{W}}{\theta}+\hat{E} \frac{2 \bar{r} \gamma_{13}\left[\theta \gamma_{8}-(\theta-1)\left[\alpha(2-\alpha) \theta \gamma_{10}+(\alpha-1) \gamma_{8}\right]\right]+\gamma_{5} \gamma_{12}\left[2 \alpha \theta^{2}+(1-2 \theta)(\alpha-1)\right]}{4 \bar{r} \theta \gamma_{10} \gamma_{13}} \\
& d U^{*}=\frac{\hat{C}^{W}}{\theta}-\hat{E} \frac{2 \bar{r} \gamma_{13}\left[\theta \gamma_{8}-(\theta-1)\left[\alpha(2-\alpha) \theta \gamma_{10}+(\alpha-1) \gamma_{8}\right]\right]+\gamma_{5} \gamma_{12}\left[2 \alpha \theta^{2}+(1-2 \theta)(\alpha-1)\right]}{4 \bar{r} \theta \gamma_{10} \gamma_{13}}
\end{aligned}
$$

The first term in the above equations is the expenditure-shifting effect of increased world demand. Due to monopolistic distortions, initial output is suboptimally low; the increased world demand resulting from expansionary monetary policy increases welfare. If preferences are identical, the second term in the above equations, the expenditure-switching effect, is zero. In this context the 
OR result is not quite so startling: absent an expenditure-switching effect, the utility effects of expansionary monetary policy are identical across countries.

In the more general case with a home-product bias, the expenditure-switching effect allows Home individuals to gain more utility as consumption rises relative to effort, but this increase is at the expense of Foreign individuals. As Figure 5(b) shows, only a small degree of home bias is required to get the familiar beggar-thy-neighbor result.

The above discussion gives new insight into the welfare effects of monetary policy. In this framework in which utility is gained from consumption but reduced with effort (i.e., output), monetary policy is 'beggar-thy-neighbor' if individuals have strong preferences for domestically produced goods. The OR result of both countries gaining equally is shown to be a special case due to the assumption of identical preferences. Finally, monetary policy can be beggar-thyself in a world in which consumers have a foreign-good bias (a preference for imported, rather than domestic, goods).

\section{Conclusions}

The model presented in this paper fully nests Obstfeld and Rogoff (1995) while allowing for a homeproduct bias in consumption. Allowing for home bias enables richer analysis of the welfare implications of monetary policy and has strong implications for exchange rate determination.

To show the implications home bias has for the welfare effects of monetary policy shocks, changes in utility are decomposed into two components, the shifting effect of increased world demand and the switching effect of an unexpected exchange rate depreciation. The shifting effect is identical across countries and is not affected by the degree of home bias. The switching effect, only apparent when there is home bias, increases Home utility at the expense of Foreign utility. With enough home bias, the switching effect is great enough that Foreign utility falls; that is, monetary policy is beggar-thy-neighbor if there is a strong enough preference for domestic goods. Conversely, if individuals prefer imported goods, monetary policy can be beggar-thyself. This decomposition provides a clear explanation of Obstfeld and Rogoff's striking result: without home bias there is no switching effect, thus utility in both countries depends only (and identically) on changes in world demand.

The model with home-product bias has a number of implications for exchange rate determination. Not surprisingly, in a model with sticky prices and different consumption baskets across countries, there are short-term deviations from PPP. This model also produces small, permanent deviations from PPP. As argued in Krugman (1990), if preferences are idiosyncratic, wealth transfers affect the real exchange rate. In my model any asymmetric shock results in a temporary current account imbalance, a permanent net foreign asset position, and, hence, permanent wealth transfers and permanent deviations from PPP. Also, with home bias there is Dornbusch (1976) type overshooting and increased volatility of real and nominal exchange rates. In this light it is not surprising that for decades economists have failed to find much evidence of PPP using U.S. dollar exchange rates, as even today the U.S. economy is relatively closed. 
The model is decidedly simple in a number of respects. Only monetary shocks are investigated here; the effects of government spending and productivity shocks in the same framework are analyzed in Warnock (1999). The absence of investment and the simplicity of the supply process preclude the model from replicating observed patterns in output. Price dynamics would have to be considerably richer, perhaps in the form of Calvo (1983) pricing, if one were to bring the model to the data. The assumption of mirror-image countries is easily relaxed if one were content with numerical solutions. 


\section{Bibliography}

Ball, Laurence and David Romer. "Are Prices Sticky?" Quarterly Journal of Economics 104 (August 1989): 507-24.

Betts, Caroline and Michael Devereux. "Exchange Rate Dynamics in a Model of Pricing-to-Market." Journal of International Economics 50 (2000): 215-244.

Blanchard, Olivier and Nobuhiro Kiyotaki.. "Monopolistic Competition and the Effects of Aggregate Demand." American Economic Review 77 (1987): 647-66.

Branson, William and Dale Henderson. "The Specification and Influence of Asset Markets," in Handbook of International Economics. Vol. 2. Eds.: Ronald Jones and Peter Kenen. Amsterdam, Elsevier Press, 1985.

Calvo, Guillermo. "Staggered Prices in a Utility Maximizing Framework." Journal of Monetary Economics 12 (1983): 983-98.

Chari, V.V., Pat Kehoe and Ellen McGratten. "Monetary Shocks and Real Exchange Rates in Sticky Price Models of International Business Cycles." Federal Reserve Bank of Minneapolis Research Department Staff Report \#223, (initial version February 1996, revised February 1998).

Corsetti, Giancarlo and Paolo Pesenti. "Welfare and Macroeconomic Interdependence." unpublished manuscript, Yale University and Princeton University, 1998.

Dixit, Avinash and Joseph Stiglitz. "Monopolistic Competition and Optimum Product Diversity." American Economic Review 67 (1977): 297-308.

Dornbusch, Rudiger. "Expectations and Exchange Rate Dynamics." Journal of Political Economy 84 (1976): 1161-76.

Engel, Charles and John H. Rogers. "How Wide is the Border." American Economic Review 86 (1996): 1112-1125.

Fleming, J. Marcus. "Domestic Financial Policies Under Fixed and Under Floating Exchange Rates." International Monetary Fund Staff Papers 9 (1962): 369-79.

Froot, Kenneth and Kenneth Rogoff. "Perspectives on PPP and Long-Run Real Exchange Rates," in The Handbook of International Economics. Vol. 3. Eds.: Gene Grossman and Kenneth Rogoff. Amsterdam, Elsevier Press, 1995.

Ghironi, Fabio. "U.S.-Europe Economic Interdependence (I): Positive Analysis." unpublished manuscript, University of California-Berkeley, 1998.

Hairault, Jean-Olivier and Frank Portier. "Money, New-Keynesian Macroeconomics and the Business Cycle." European Economic Review 37 (1993): 1533-1568. 
Hau, Harald. "Exchange Rate Determination: The Role of Factor Price Rigidities and Nontradables." Journal of International Economics, forthcoming.

Isard, Peter. "How Far Can We Push the 'Law of One Price'?" American Economic Review 67 (1977): 942-48.

Koenig, Evan. "Real Money Balances and the Timing of Consumption: An Empirical Investigation." Quarterly Journal of Economics 105 (1990): 399-425.

Krugman, Paul. "Equilibrium Exchange Rates," in International Monetary Policy Coordination and Exchange Rate Fluctuations. Eds.: William Branson, Jacob Frenkel and Morris Goldstein. Chicago: U. of Chicago Press, 1990, pp 159-187.

Lane, Philip R., "The New Open Economy Macroeconomics: A Survey." CEPR Discussion Paper No. 2115, March 1999.

MacDonald, Ronald. Floating Exchange Rates: Theories and Evidence. London, Unwin-Hyman, 1988.

Machlup, F. International Trade and the National Income Multiplier. Philadelphia: Blakiston, 1943.

Mankiw, N. Gregory. "Small Menu Costs and Large Business Cycles: A Macroeconomic Model of Monopoly." Quarterly Journal of Economics 100 (1985): 529-538.

Mankiw, N. Gregory and Lawrence Summers. "Money Demand and the Effects of Fiscal Policy." Journal of Money, Credit and Banking 18 (1986): 415-29.

Meade, J.E. The Balance of Payments. London: Oxford University Press, 1951.

Mundell, Robert A. "Capital Mobility and Stabilization Policy Under Fixed and Flexible Exchange Rates." Canadian Journel of Economics 29 (1963):475-85. . International Economics. New York: MacMillan, 1968.

Obstfeld, Maurice and Kenneth Rogoff. "Exchange Rate Dynamics Redux." Journal of Political Economy 103 (1995): 624-660. . Foundations of International Macroeconomics. Cambridge, MA: MIT Press, 1996.

Obstfeld, Maurice and Kenneth Rogoff. "New Directions for Stochastic Open Economy Models." Journal of International Economics 50 (2000): 117-153.

Sutherland, Alan. "Exchange Rate Dynamics and Financial Market Integration." CEPR Discussion Paper 1337 (1996). 
Tille, Cedric. "The International and Domestic Welfare Effects of Monetary Policy Under Pricing-toMarket." unpublished manuscript, Princeton University, 1998.

Warnock, Francis E. "Idiosyncratic Tastes in a Two-Country Optimizing Model: Implications of a Standard Presumption." Board of Governors of the Federal Reserve System, International Finance Discussion Paper No. 631, 1999. 


\section{Figures}

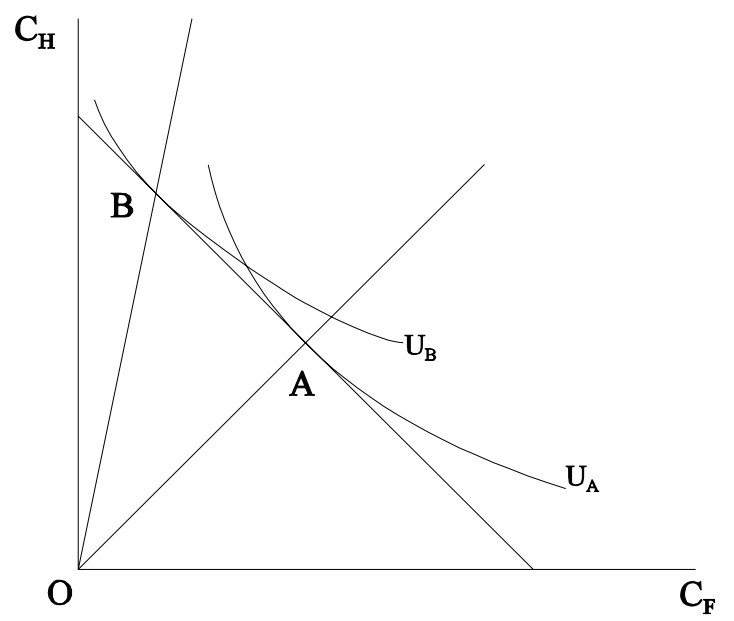

Figure 1: A Home Individual's Intratemporal Consumption Choice 
Figure 2: Short-run changes from an unanticipated permanent increase in Home money supply. Pre-shock equilibrium is at the origin. Primed, thick curves and the post-shock equilibrium A are drawn for $\alpha>1$; unprimed curves and point B are drawn for $\alpha=1$.

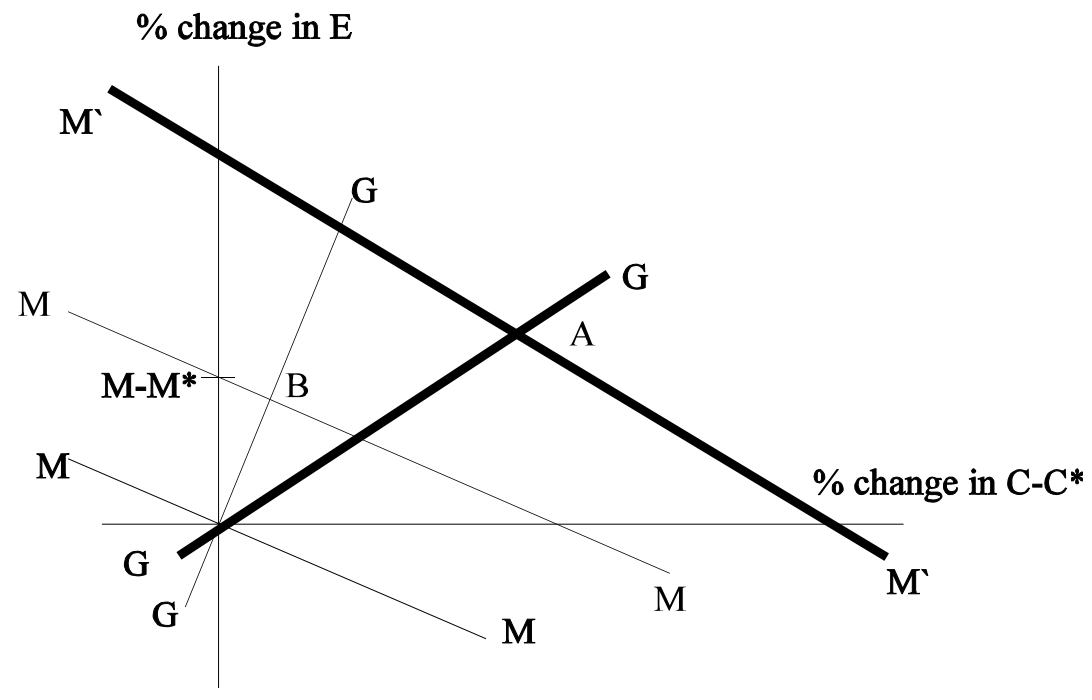



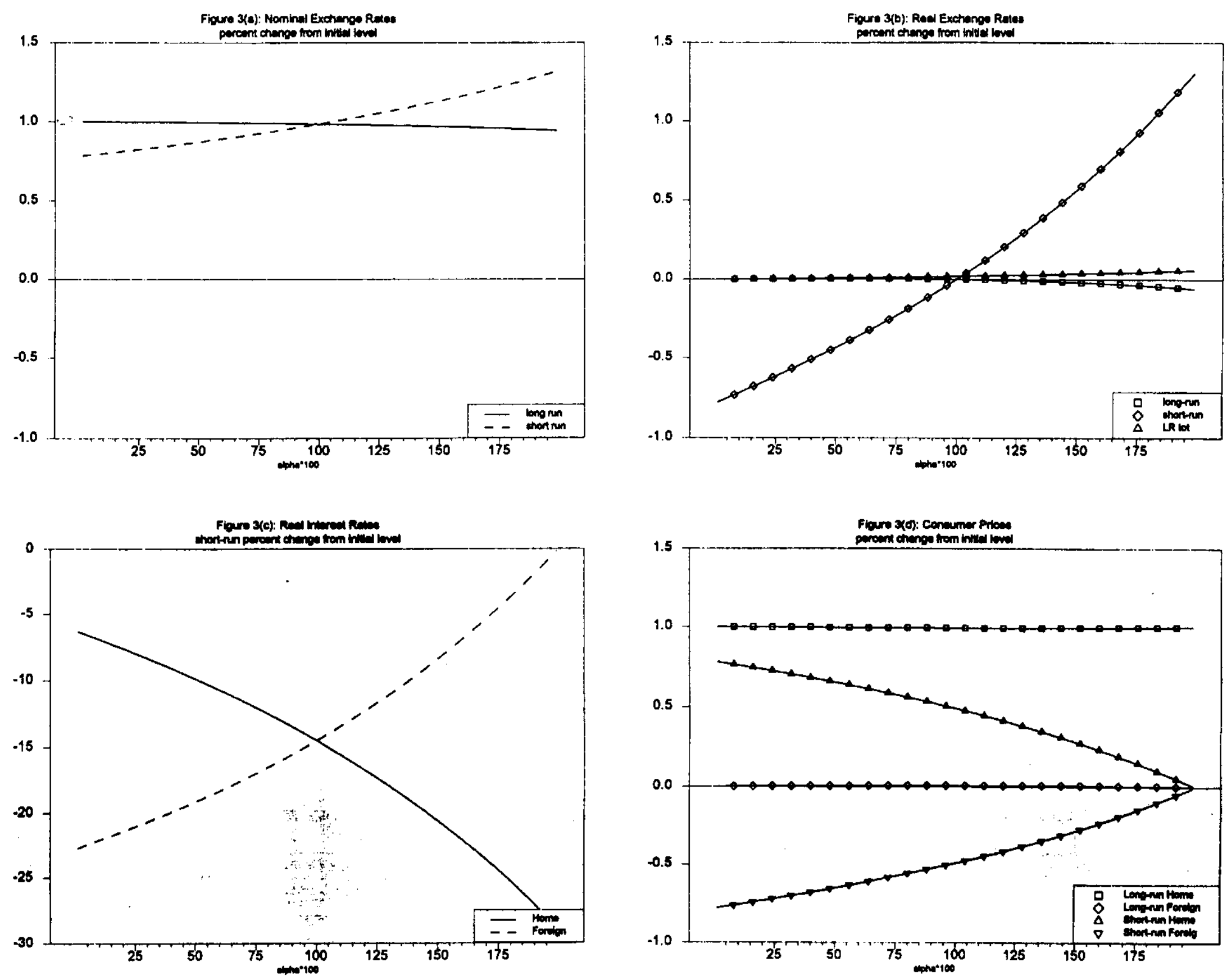

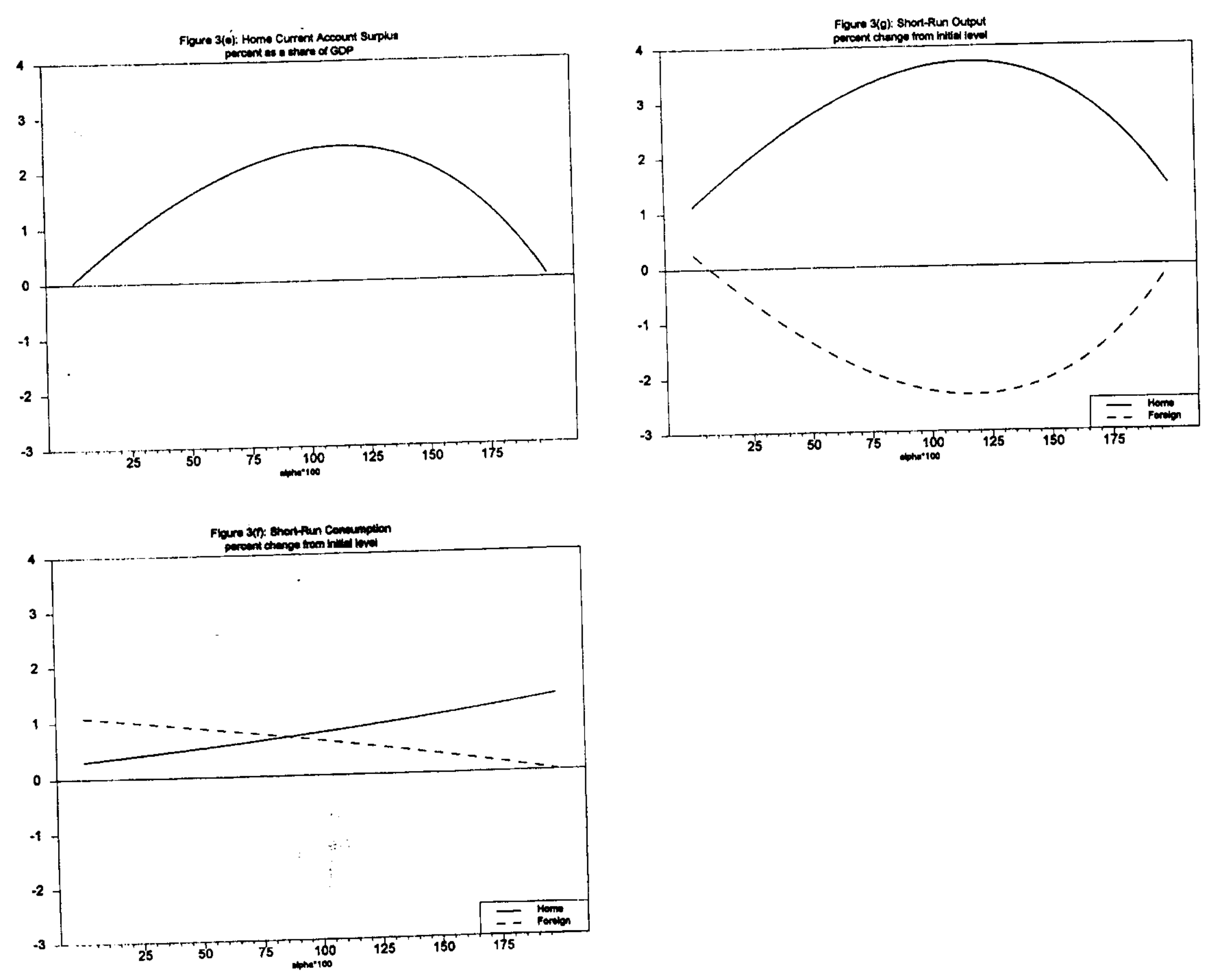

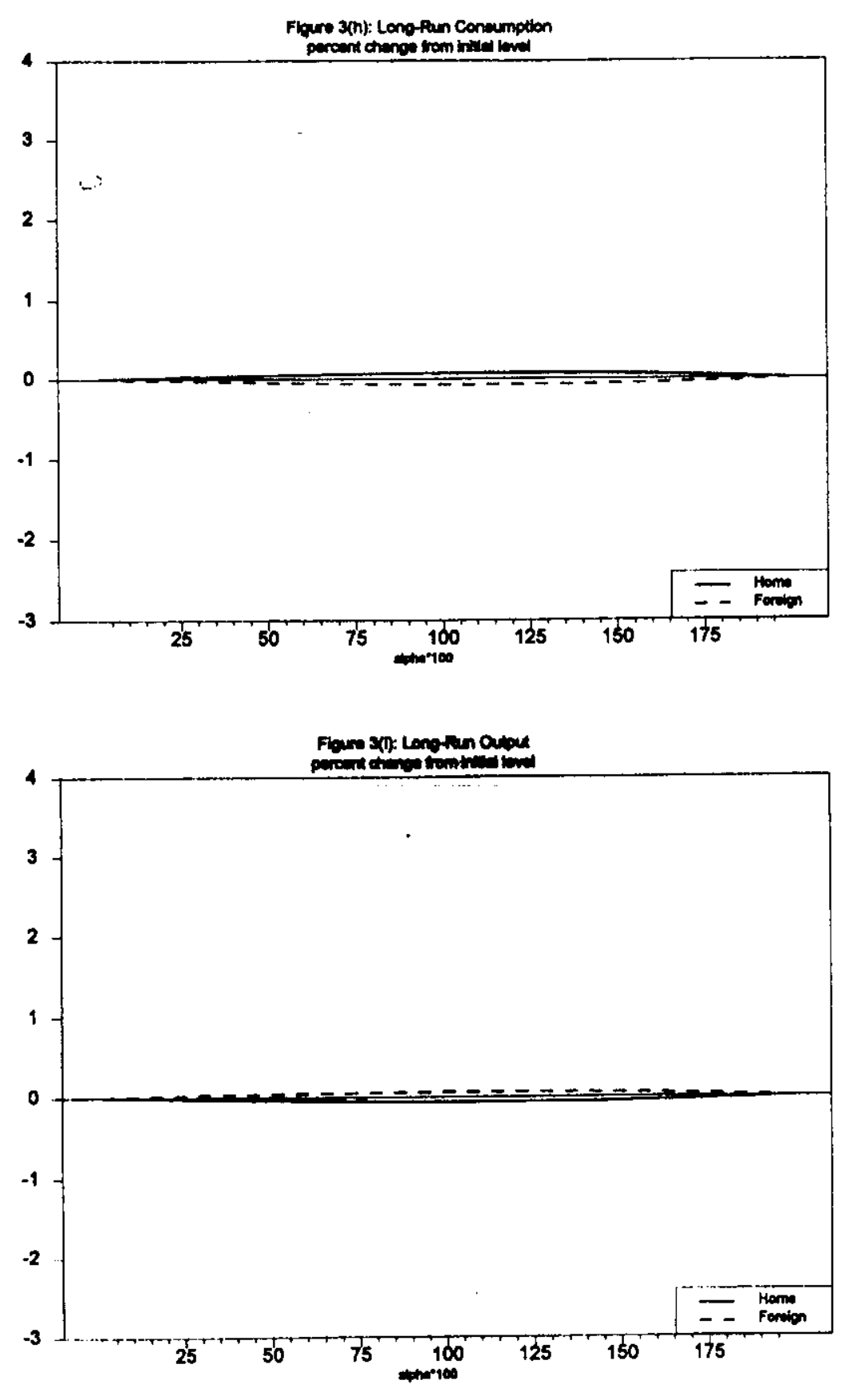


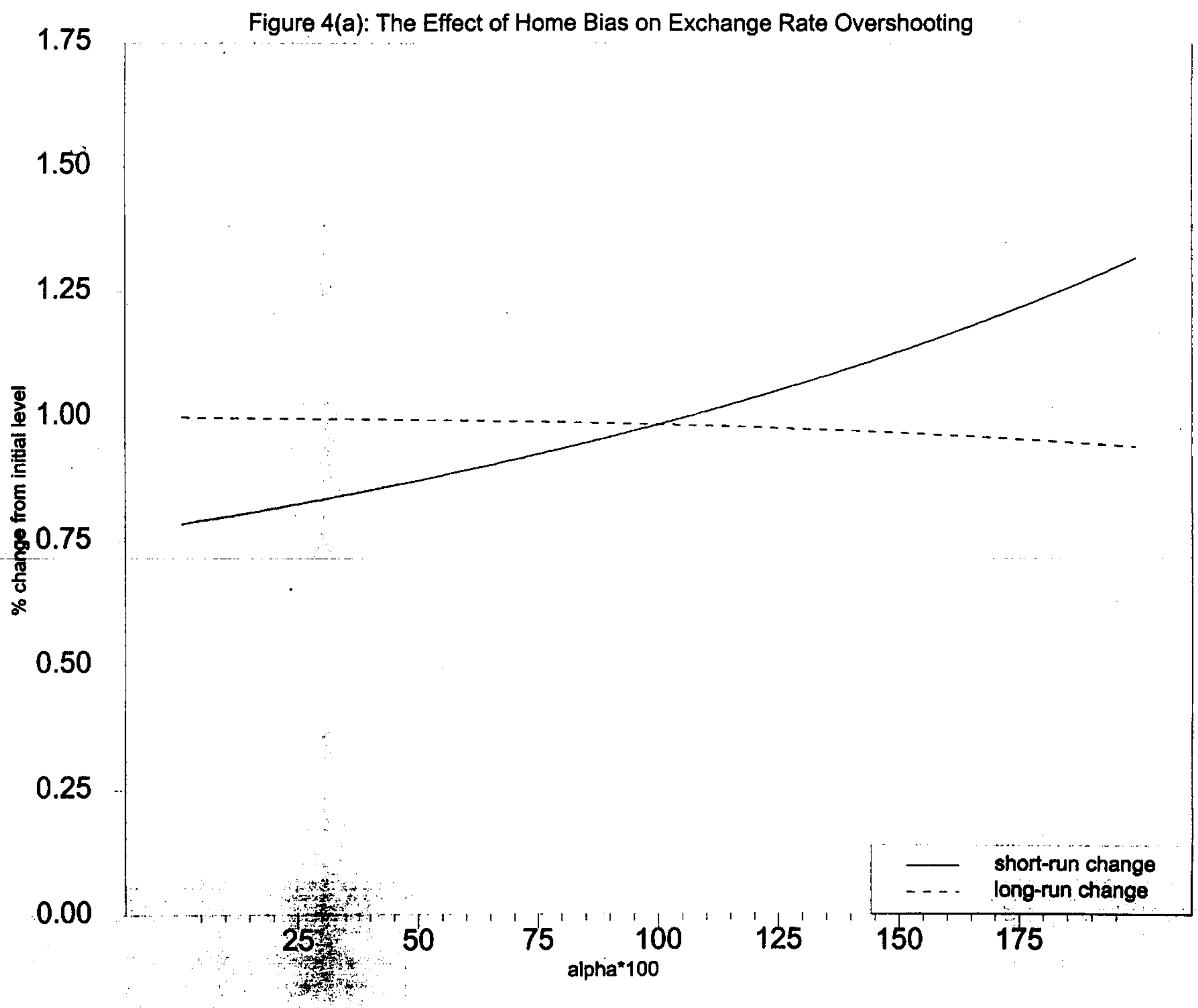


Figure 4(b): The Effect of the Consumption Elasticity of Money Demand

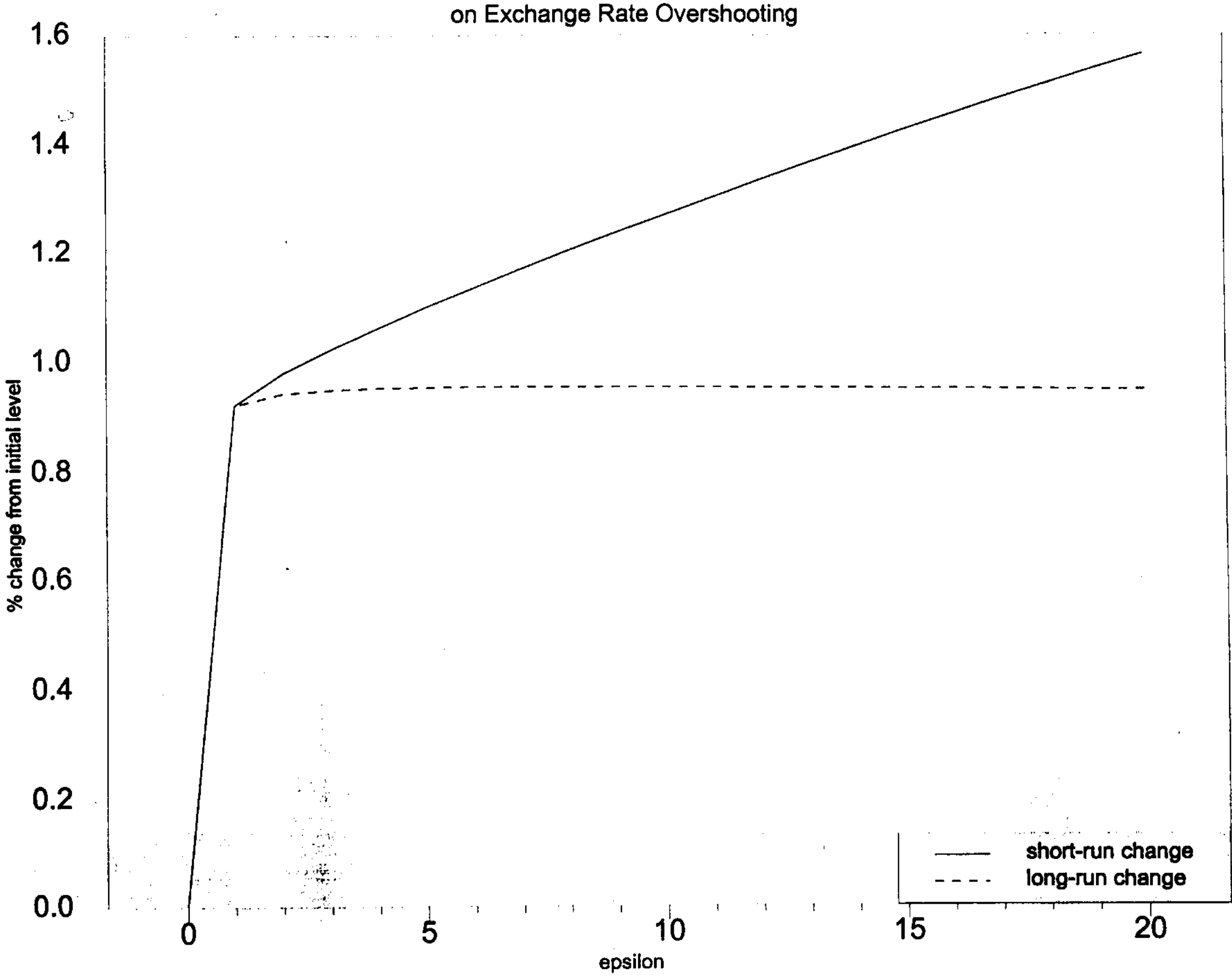



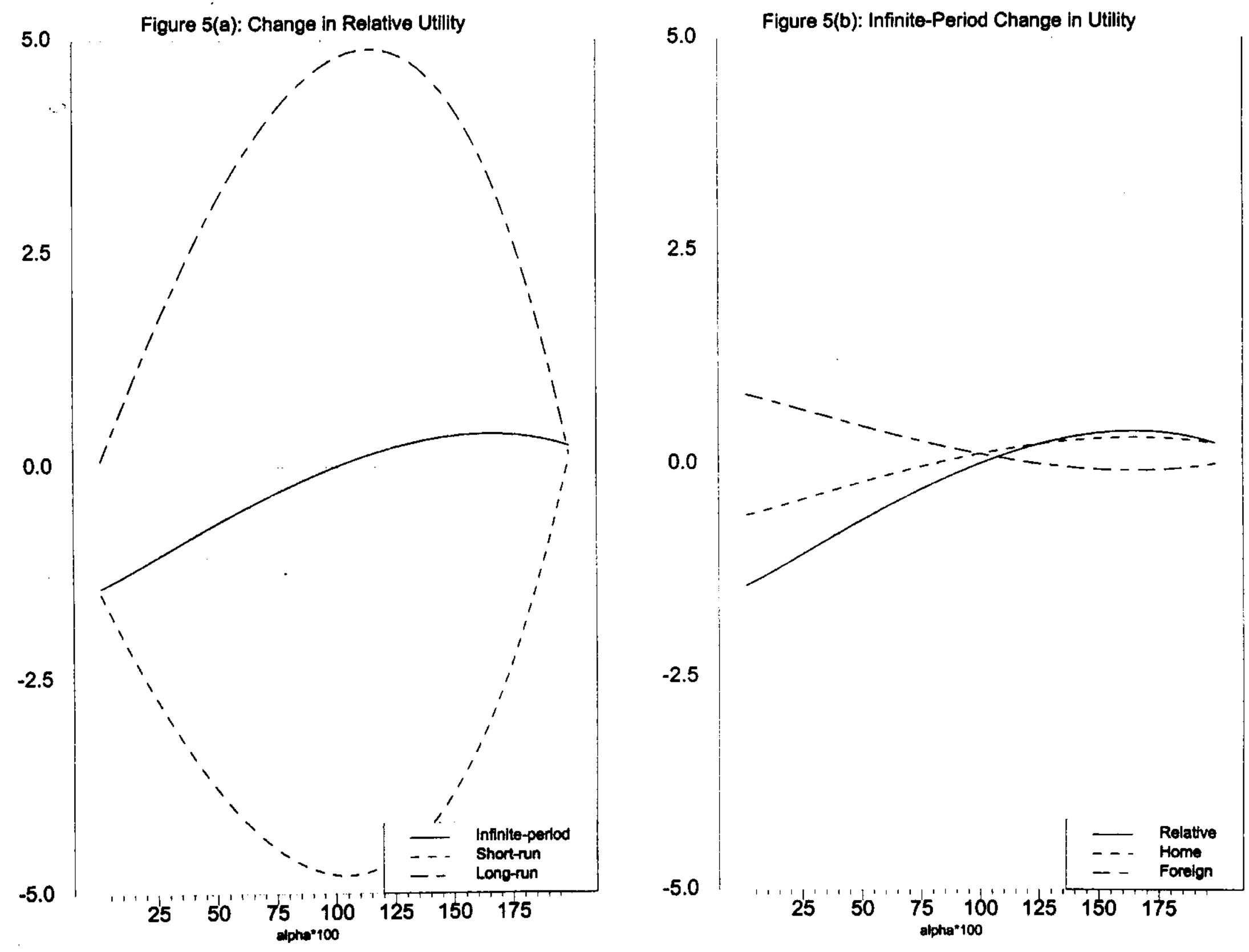


\section{Appendix: Analytical Solutions}

$$
\begin{aligned}
& \hat{E}=\left(\tilde{M}-\tilde{M}^{*}\right) \frac{\varepsilon(1+\bar{r} \varepsilon) \gamma_{0} \gamma_{10}}{\gamma_{11}} \\
& \tilde{E}=\frac{\varepsilon\left(\tilde{M}-\tilde{M}^{*}\right)}{\gamma_{8} \gamma_{11}}\left((1+\bar{r} \varepsilon(2-\alpha)) \gamma_{9} \gamma_{10}-\bar{r} \gamma_{8}\left(\gamma_{7} \gamma_{10}+\alpha \gamma_{2} \gamma_{8}\right)\right) \\
& \tilde{\tau}=\left(\tilde{M}-\tilde{M}^{*}\right) \frac{\alpha \bar{r} \varepsilon(\theta+1) \gamma_{0} \gamma_{12}}{2 \gamma_{11} \gamma_{13}} \\
& \frac{d \bar{B}}{\bar{y}_{0}}=\left(\tilde{M}-\tilde{M}^{*}\right) \frac{(1-\alpha / 2) \varepsilon(1+\bar{r} \varepsilon) \gamma_{0} \gamma_{12}}{\gamma_{11}} \\
& \hat{P}=-\hat{P}^{*}=\left(\tilde{M}-\tilde{M}^{*}\right) \frac{(2-\alpha) \varepsilon \gamma_{9} \gamma_{10}}{2 \gamma_{8} \gamma_{11}} \\
& \tilde{P}=\tilde{M}^{W}+\left(\tilde{M}-\tilde{M}^{*}\right)\left(1 / 2-\frac{(1+\alpha \theta) \gamma_{5} \gamma_{9} \gamma_{12}}{4 \gamma_{8} \gamma_{11} \gamma_{13}}\right) \\
& \tilde{P}^{*}=\tilde{M}^{W}-\left(\tilde{M}-\tilde{M}^{*}\right)\left(1 / 2-\frac{(1+\alpha \theta) \gamma_{5} \gamma_{9} \gamma_{12}}{4 \gamma_{8} \gamma_{11} \gamma_{13}}\right) \\
& \hat{y}=\frac{1+\bar{r} \varepsilon}{(1+\bar{r})} \tilde{M}^{W}+\frac{\varepsilon \gamma_{9}\left(\alpha(2-\alpha) \theta \gamma_{10}+(\alpha-1) \gamma_{8}\right)}{2 \gamma_{8} \gamma_{11}}\left(\tilde{M}-\tilde{M}^{*}\right) \\
& \hat{y}^{*}=\frac{1+\bar{r} \varepsilon}{(1+\bar{r})} \tilde{M}^{W}-\frac{\varepsilon \gamma_{9}\left(\alpha(2-\alpha) \theta \gamma_{10}+(\alpha-1) \gamma_{8}\right)}{2 \gamma_{8} \gamma_{11}}\left(\tilde{M}-\tilde{M}^{*}\right) \\
& \tilde{y}=-\tilde{y}^{*}=\left(\tilde{M}-\tilde{M}^{*}\right) \frac{-\varepsilon(1-\alpha+\alpha \theta) \gamma_{5} \gamma_{9} \gamma_{12}}{4 \gamma_{8} \gamma_{11} \gamma_{13}} \\
& \hat{C}=\frac{1+\bar{r} \varepsilon}{(1+\bar{r})} \tilde{M}^{W}+\frac{\varepsilon \gamma_{9}}{2 \gamma_{11}}\left(\tilde{M}-\tilde{M}^{*}\right) \\
& \hat{C}^{*}=\frac{1+\bar{r} \varepsilon}{(1+\bar{r})} \tilde{M}^{W}-\frac{\varepsilon \gamma_{9}}{2 \gamma_{11}}\left(\tilde{M}-\tilde{M}^{*}\right) \\
& \tilde{C}=-\tilde{C}^{*}=\left(\tilde{M}-\tilde{M}^{*}\right) \frac{(1+\alpha \theta) \varepsilon \gamma_{5} \gamma_{9} \gamma_{12}}{4 \gamma_{8} \gamma_{11} \gamma_{13}} \\
& \hat{r}=-\frac{1+\bar{r} \varepsilon}{\bar{r} \beta(1+\bar{r})} \tilde{M}^{W}-(\alpha-1) \varepsilon \gamma_{9}\left(\frac{2(2-\alpha) \gamma_{10} \gamma_{13}+\alpha \gamma_{5} \gamma_{12}}{4(2-\alpha) \bar{r} \beta \gamma_{8} \gamma_{11} \gamma_{13}}\right)\left(\tilde{M}-\tilde{M}^{*}\right) \\
& \hat{r}^{*}=-\frac{1+\bar{r} \varepsilon}{\bar{r} \beta(1+\bar{r})} \tilde{M}^{W}+(\alpha-1) \varepsilon \gamma_{9}\left(\frac{2(2-\alpha) \gamma_{10} \gamma_{13}+\alpha \gamma_{5} \gamma_{12}}{4(2-\alpha) \bar{r} \beta \gamma_{8} \gamma_{11} \gamma_{13}}\right)\left(\tilde{M}-\tilde{M}^{*}\right)
\end{aligned}
$$


where

$\underline{\alpha \in(0,2)}$

$\gamma_{0} \equiv(2-\alpha)(\alpha \theta+1)+\alpha(\alpha-1)$

$\gamma_{1} \equiv 1-\alpha+\varepsilon+\bar{r} \varepsilon^{2}(2-\alpha)$

$\gamma_{2} \equiv(\varepsilon-1)(\alpha-1)$

$\gamma_{3} \equiv 2(1+\theta-\alpha)$

$\gamma_{4} \equiv(1-\alpha)\left(2 \theta(2-\alpha)-\gamma_{3}\right)$

$\gamma_{5} \equiv(2-\alpha) \bar{r}(\theta+1)$

$\gamma_{6} \equiv(\alpha-1) \gamma_{3}+(\alpha \theta-1) \gamma_{5}$

$\gamma_{7} \equiv \gamma_{0} \gamma_{1}+\alpha(1-\alpha) \gamma_{2}$

$\gamma_{8} \equiv \gamma_{0} \gamma_{6}+\alpha(1-\alpha) \gamma_{4}$

$\gamma_{9} \equiv \gamma_{0} \gamma_{8}(1+\bar{r} \varepsilon)$

$\gamma_{10} \equiv \gamma_{0}\left(\gamma_{3}+\gamma_{5}\right)-\alpha \gamma_{4}$

$\gamma_{11} \equiv \gamma_{7} \gamma_{10}+\gamma_{9}+\alpha \gamma_{2} \gamma_{8}$

$\gamma_{12}=\gamma_{10}(\alpha \theta-1)-\gamma_{8}$

$\gamma_{13}=\theta(1+\alpha \theta)+(1-\alpha)$ $\underline{\alpha=1}$

$\gamma_{0}=\theta+1$

$\gamma_{1}=\varepsilon(1+\bar{r} \varepsilon)$

$\gamma_{2}=0$

$\gamma_{3}=2 \theta$

$\gamma_{4}=0$

$\gamma_{5}=\bar{r}(\theta+1)$

$\gamma_{6}=\bar{r}\left(\theta^{2}-1\right)$

$\gamma_{7}=\varepsilon(1+\bar{r} \varepsilon)(\theta+1)$

$\gamma_{8}=\bar{r}(\theta+1)\left(\theta^{2}-1\right)$

$\gamma_{9}=\bar{r}(1+\bar{r} \varepsilon)(\theta+1)^{2}\left(\theta^{2}-1\right)$

$\gamma_{10}=(\theta+1)(\bar{r}(\theta+1)+2 \theta)$

$\gamma_{11}=(1+\bar{r} \varepsilon)(\theta+1)^{2}\left[\varepsilon(\bar{r}(\theta+1)+2 \theta)+\bar{r}\left(\theta^{2}-1\right)\right]$

$\gamma_{12}=2 \theta\left(\theta^{2}-1\right)$

$\gamma_{13}=\theta(\theta+1)$ 